\title{
The Role of Viruses in Bioterrorism: A Review with Emphasis on Coronaviruses
}

Abstract
Introduction: Bioterrorism refers to the deliberate spread of
biological agents among human and animal societies, causing
irreparable damage, such as fatality, recession and social stress.
The aim of this study is to investigate the role of viruses in
bioterrorism, with emphasis on Coronavirus Disease 2019
(COVID-19), the effect of this virus on the future of the world,
and its use in bioterrorism.
Method: This study is a narrative review based on available
literature in both English and Persian languages by searching for
a combination of keywords including bioterrorism, viral diseases
and COVID-19 in databases such as PubMed, Google Scholar,
Science Direct, Cochrane Library, Scopus and Magiran.
Results: The results of the available literature review are presented
in different subtitles, including history, viral biological weapons,
emerging infectious diseases and future challenges.
Conclusion: The use of viruses will be a reasonable choice to
overthrow nations due to their high spread and lethality, lack of
conflict on the battlefield, or high economic and human costs.
COVID-19 will present new aspects of bioterrorism impacts on
the world's population and economy. Therefore, the tragedy of
COVID-19 is not just about its current mortality, and in the near
future, we can expect even more complicated problems. Future
bioterrorism is therefore different from what we have seen in the
past.

Keywords:Bioterrorism ${ }^{\{1\}}$, Virus diseases ${ }^{\{2\}}$, COVID-19 ${ }^{\{3\}}$, Biological agents $\{4\}$

\section{Article Info}

Authors:

Aramideh khouy $\mathrm{R}^{1}$

Hosseini Tehrani $\mathrm{M}^{1}$ (D)

Zarali $\mathrm{MR}^{2}$

Maleki $\mathrm{H}^{2 *}$ (D)

Moazeni $\mathrm{B}^{2}$ (D)

Received:2020.4.2

Accepted:2020.4.30

E-Published:2020.5.25

\footnotetext{
Affiliations

*Researcher, Armed forces health administration of Islamic Republic of Iran, Tehran, Iran. ana.homayon@yahoo.com Tel: +989128701603
}

\section{Citation Subjects:}

$\{\{1\}$ Biological Terrorism, Biological Warfare $\{2\}$ Viral Diseases, Viral Infections

\{3\} COVID-19 Pandemic, COVID-19 Virus Disease, COVID-19 Virus Infection, SARS Coronavirus 2 Infection, SARS-CoV-2 Infection $\{4\}$ Biological Factor 
فصلنامه يرستار و يزشك در رزم / بهار 99 / سال هشتم

مقاله مرورى

\section{مرورى بر نقش ويروسها در بيوتروريسه: با تاكيد بر كرونا ويروسها}

\section{اطلاعات مقاله}

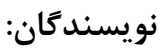

رضا آرميده خوى' - مونسين

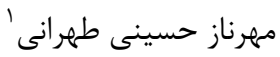

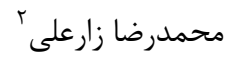

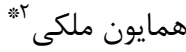

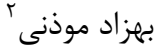

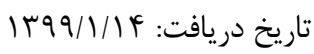

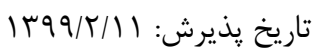

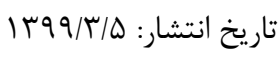

\section{جكبده}

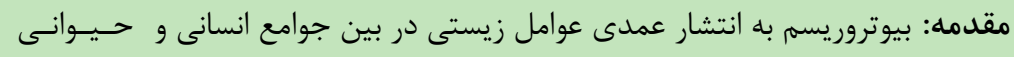

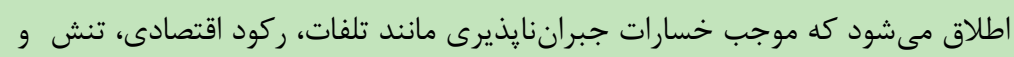

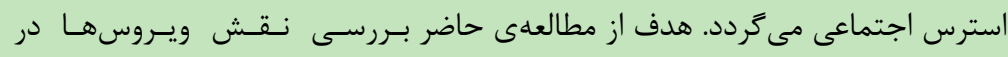

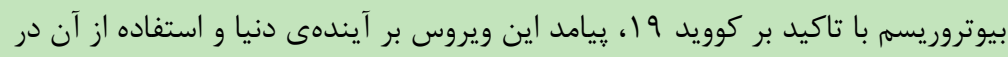
بيوتروريسم مى باشد.

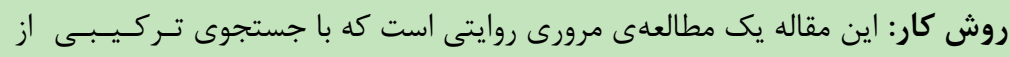

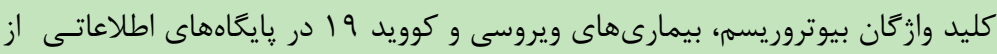

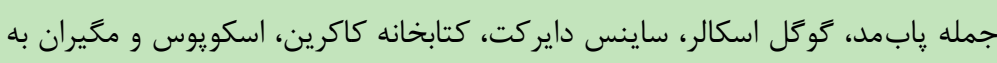

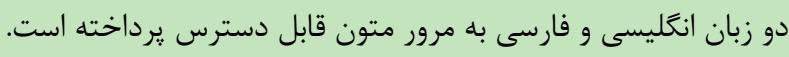

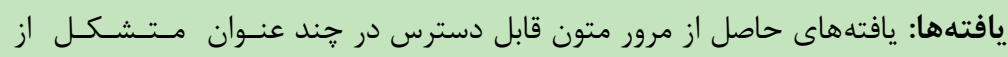

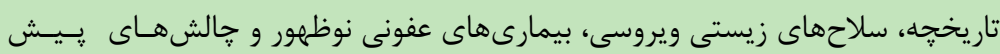
روى كوويد 19 بيان شده است. نتان.

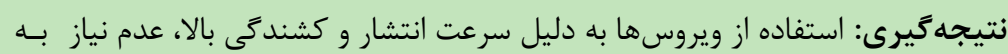

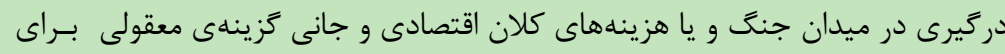

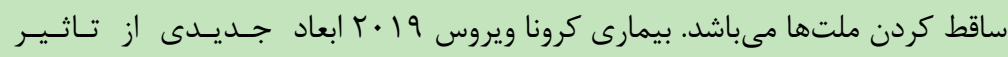

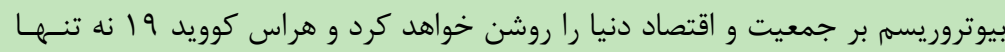

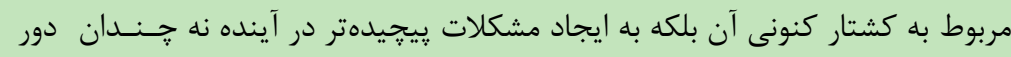

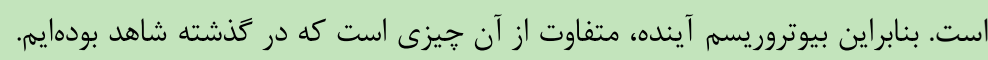

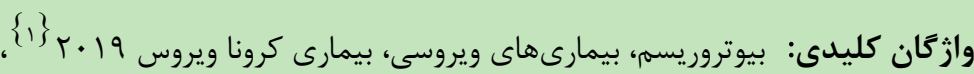

$$
\begin{aligned}
& \text { عوامل بيولوزيكى }
\end{aligned}
$$

$$
\begin{array}{r}
\text { عناوين ارجاعى: } 19 \text { \{1 } 19 \text { كوويد } 19 \text { عوامل زيستى }
\end{array}
$$

\section{وابستكى سازمانى نويسندكان}

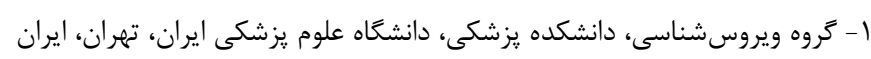

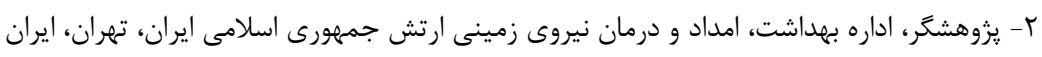
ana.homayon@yahoo.com Tel: +989128701603 


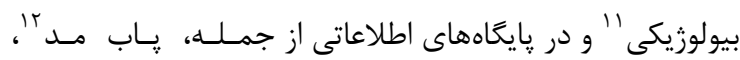

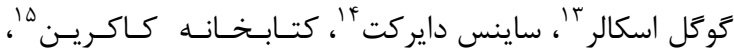

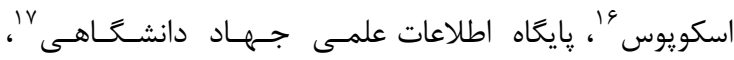

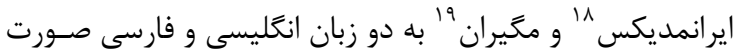
يذيرفت. علاوه بر جستجو در يايگاههاى معتبر ذكر شده برخى دئى

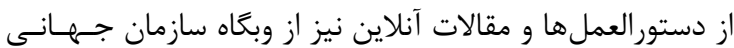

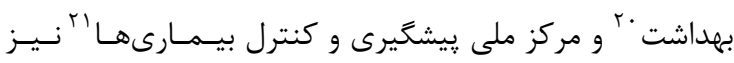
ستخراج گرديد.

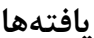

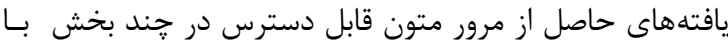

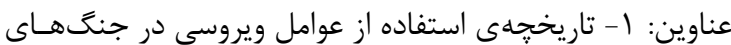

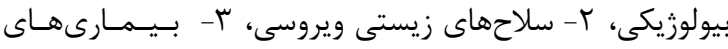

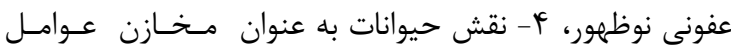
بيولوزيك و ه- جالشهاى پيش رون روى بشر بعد از بيمارى كرونـا

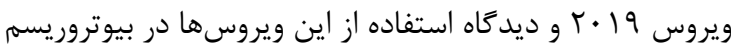
به صورت مستقيم و غيرمستقيم توصيف شده است.

|- ا-تاريخجه

استفاده از سلاحهاى بيولوزيكى در جنَ مفهوم جديدى نيست،

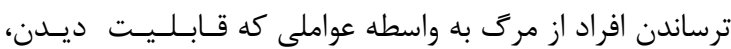

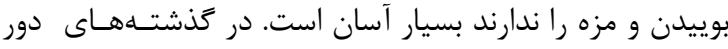

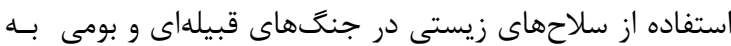
روشهاى مختلف مرسوم بوده است. مطالعات نشان دادهاند كـهـ بيمارىهاى مسرى و ساير سلاحهاى بيولوزيكى به دليل تأثـيــر

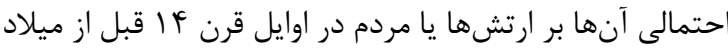

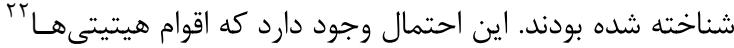

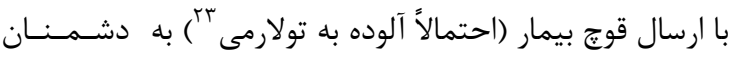

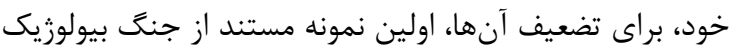

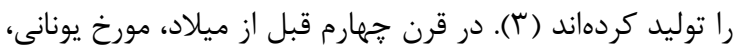

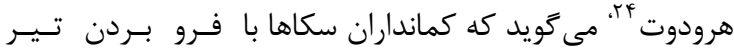

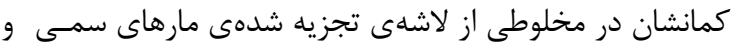

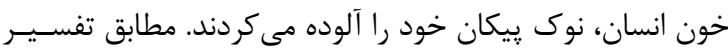

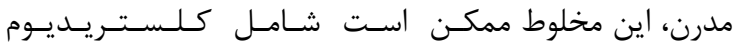

11- Biological warfare

12- PubMed

13- Google scholar

14- Science direct

15- Cochrane Library

16- Scopus

17- Scientific information database (SID)

18- Iranmedex

19- Magiran

20- World Health Organization (WHO)

21- Centers for Disease Control and Prevention (CDC)

22- Hittites

23- Tularaemia

24- Herodotus
بيوتروريسم' استفاده از ميكروار كانيسهها (ويروس ها، باكترىهـا

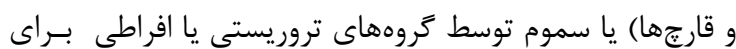

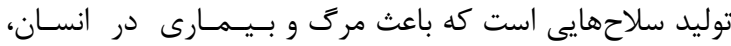

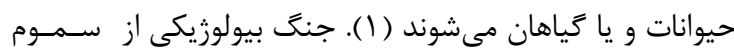
بيولوزيكى يا عوامل عفونى مانند ويروسها، باكترىها و يا قارجها

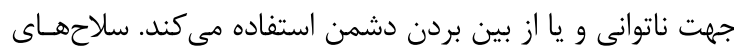

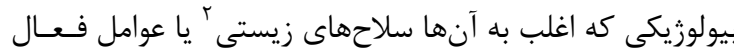

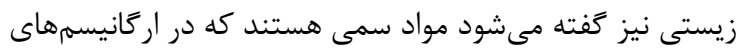
بيمارىزا توليد مىشوند. ميكروار گانيسمهايى كه به صورت خود

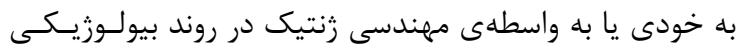

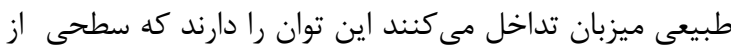

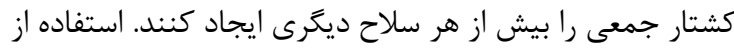

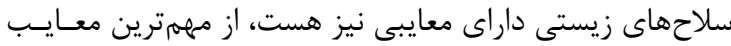

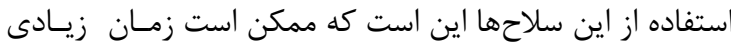

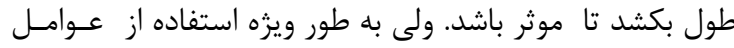

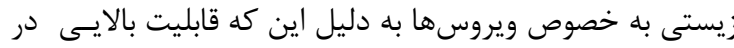

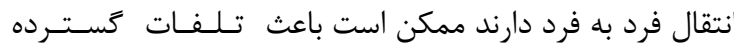

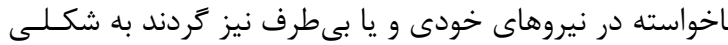

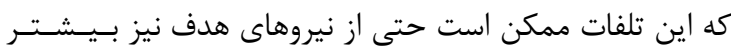

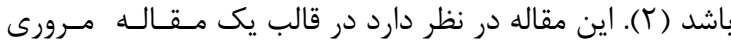

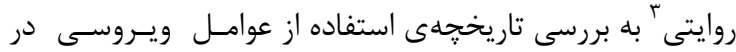

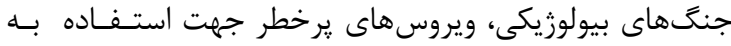

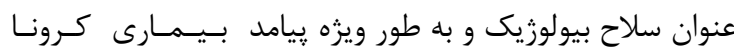

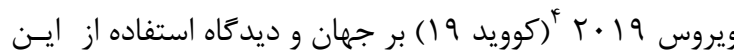
ويروس در بيوتروريسم به صورت مستقيم و غيرمستقيم بيردازد.

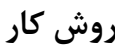

مطالعهى حاضر با روش مرور روايتى بر مطالعات و يافـتههــاى ماى

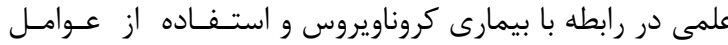

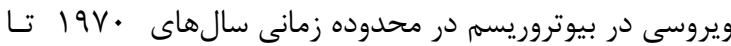

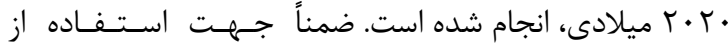

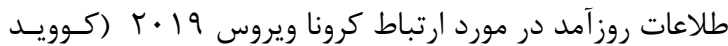

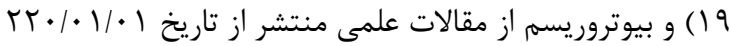

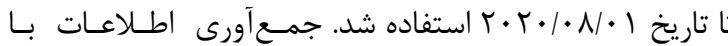

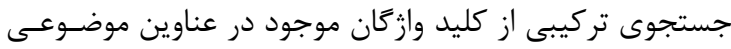

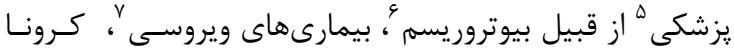

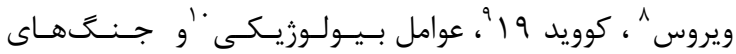

1- Bioterrorism

2- Biological Weapons-2

3- Narrative Review

4- Coronavirus disease2019 4

5- Medical Subject Headings (MeSH)

6- Bioterrorism

7- Virus diseases

8- Corona virus

9- COVID-19

10- Biological agents 
دسترسى به اين عوامل در سه گروه A، B و Cطبقهبندى كرده

كروه A: عوامل زيستى كه توانايى انتقال سريع و راحت در بين

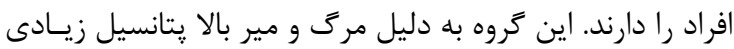

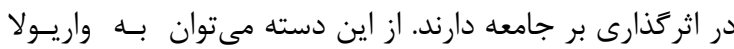

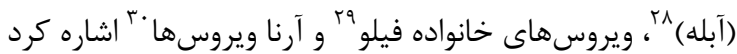

كروه B: دومين گروه در اين طبقهبندى ويروس). (ائى هستند كه توانايى عفونتزايى متوسطى دارند. اين گروه مانند گروه اول نيز

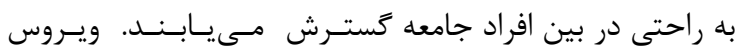

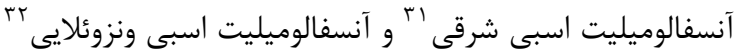
در اين گروه جاى دارند (جدول (1). كروه C: سومين دستهبندى متعلق به ياتوزن هاى نوظهور است،

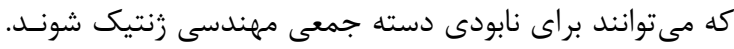

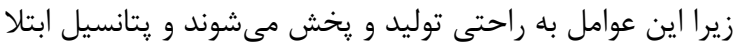

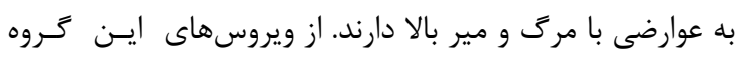

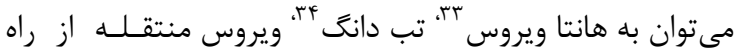

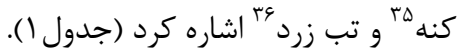

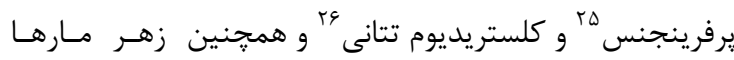

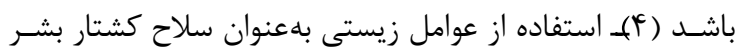

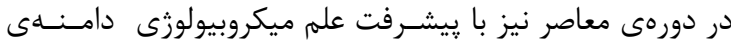

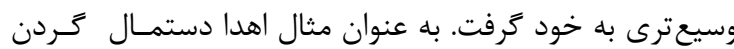

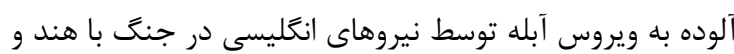

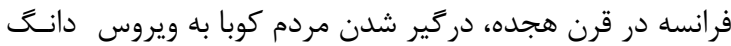

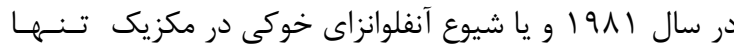

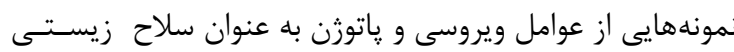

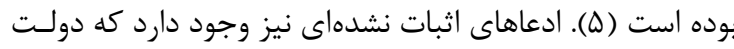

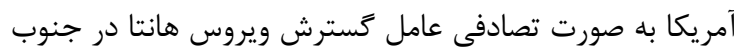

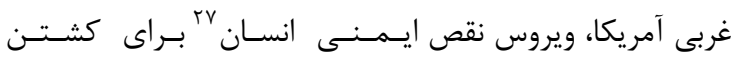

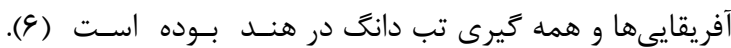

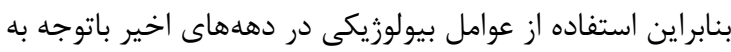

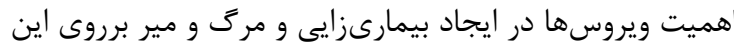
عامل متمر كز شده است.

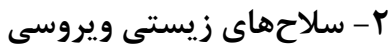

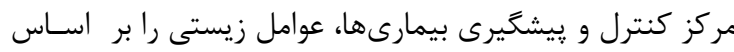

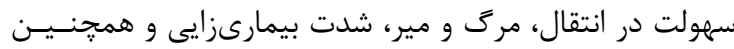

\section{جدول ا. طبقهبندى عوامل ويروسى كه در بيوتروريسم نقش دارند (V)}

\begin{tabular}{|c|c|c|c|}
\hline عامل ويروسى & بيمارى & ويثزى & طبقدبندى \\
\hline خانواده پاكس (واريولا) & آبله انسانى & \multirow{3}{*}{ 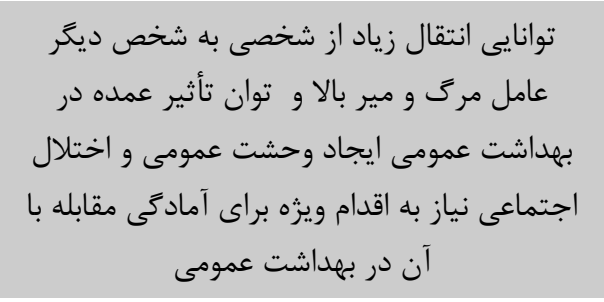 } & \multirow{3}{*}{ تروه A } \\
\hline $\begin{array}{c}\text { خانواده فيلو ويروس (ماربورت و ابولا) } \\
\text { خاريا }\end{array}$ & تبهاى خونريزىدهنده & & \\
\hline 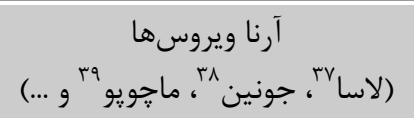 & تب، ميالرى، مننريت & & \\
\hline 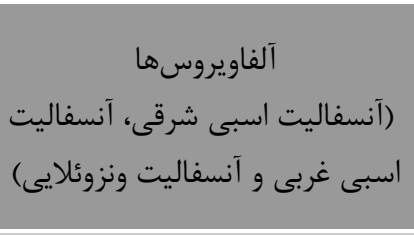 & آنسفاليتهاى ويروسى & 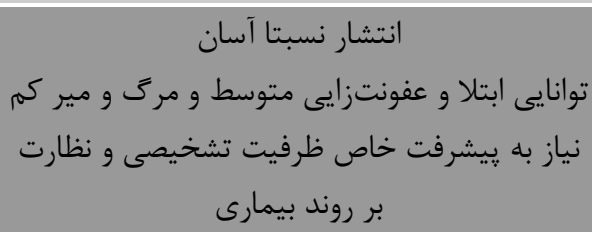 & كروه B \\
\hline 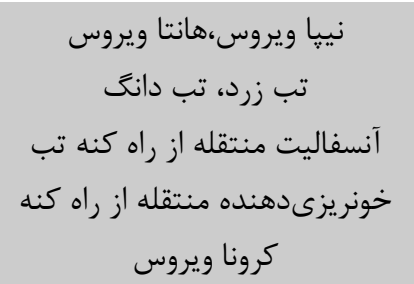 & بيمارىهاى عفونى & 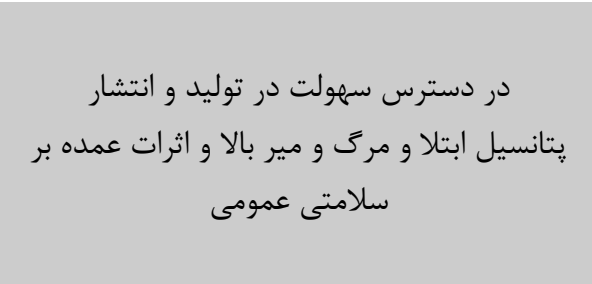 & كروه C \\
\hline
\end{tabular}

28- Small Pox

29- Filoviridae

30- Arenaviridae

31- Eastern equine encephalomyelitis virus (EEEV)

32- Venezuelan equine encephalomyelitis virus (VEEV)

33- Hantavirus 7

34- Dengue virus

35- Tick-borne encephalitis virus

36- Yellow fever virus

37- Lassa fever

38- Junin

39- Machupo

25- Clostridium perfringens

26- Clostridium tetani

27- Human immunodeficiency virus (HIV)-27 
سلولى تكثير و توسط يك تروريست در بين افـراد و جـامـــــ

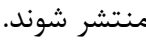

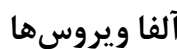

اين ويروسها به دليل پايدارى زياد، عفونى بودن قابلتـوجـهـ و و

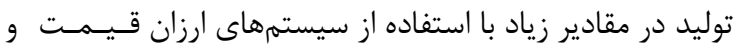
غير يِجِيده براى سلامت بشريت نگران كننده هستند. سويلهايى

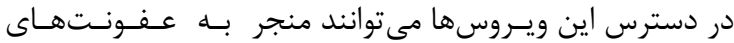

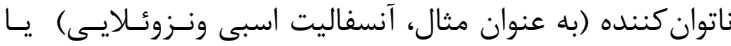

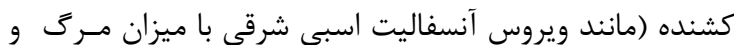

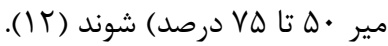

\section{| - بيمارى هاى عفونى نوظهور} بيمارىهاى عفونى نوظهور كه حداقل بإى آدرصد از كل عـوامـل

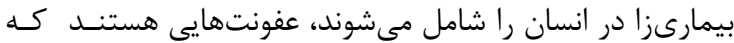

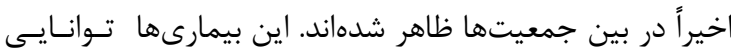

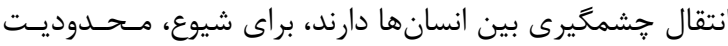

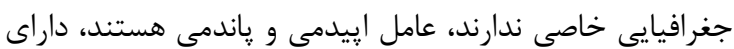

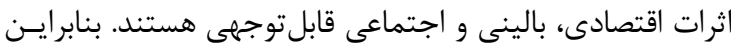

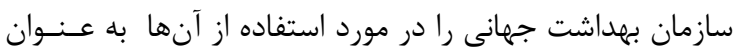

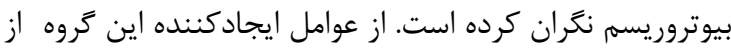

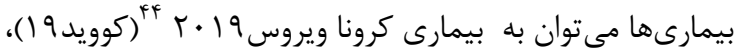
سويههاى جديد آنفلوانزا و ويروس نقص بيماري كرونا ويموسنى انسان اشاره كرد

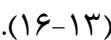

\section{كرونا ويروسهi}

كرونا ويروس انسان براى اولين بار در دهه • •9 أدر بـيـمـاران

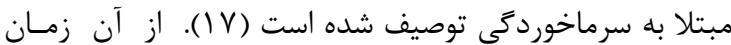

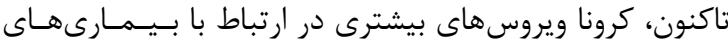

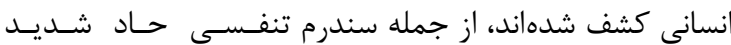

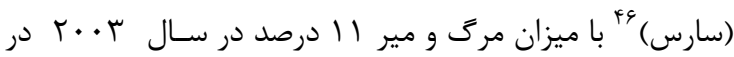

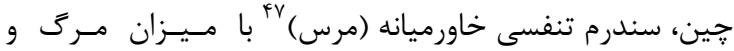

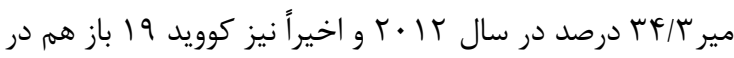
جين كه به محض عفونت توانايى تبديل به يك بيمارى كشــــده

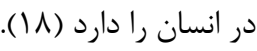

\section{طبقهبندى كرونا ويروسها} كرونا ويروسها بر اساس تكامل نزادى به جههار گروه آلفا (مانـــد

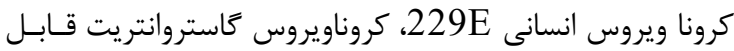

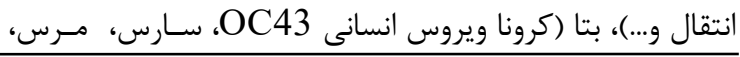

44- Corona virus disease 2019(COVID- 19)

45- Corona virus- 45

46- Severe acute respiratory syndrome (SARS)-

47- Middle East respiratory syndrome (MERS)-47

\section{واريولا مازور (آبله انسانى)}

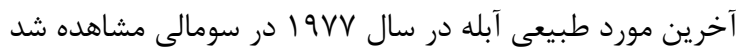

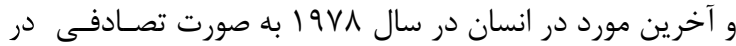

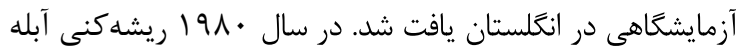

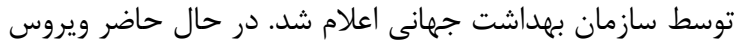

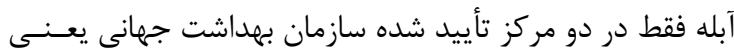
مركز كنترل و يِشخيرى از بيمارىها در ايالات متحده (آتلانتـا)

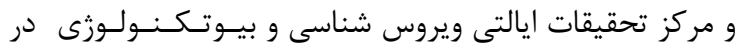
روسيه قرار دارد (^). ويروس واريولا در صورت استفاده به عنوان سلاح زيستى يك تهديد بالقوه براى جمعيتهاى غير نظامى به ودرد

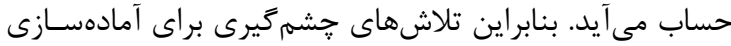

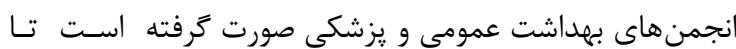

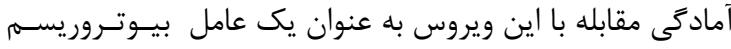

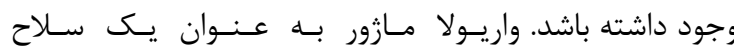

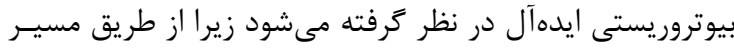

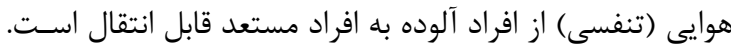

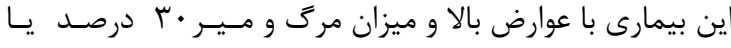

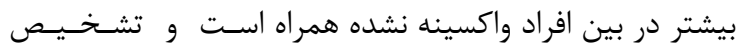

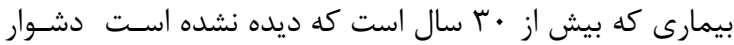

(9) (9) (9) (1)

\section{تبهاى خونريزى دهنده}

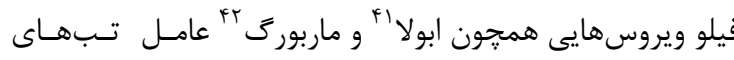
خونريزىدهندهايى هستند كه مىتوانند از طريق مسير هوايسى،

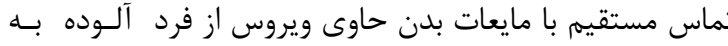

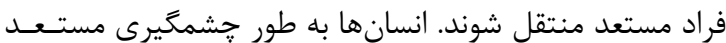

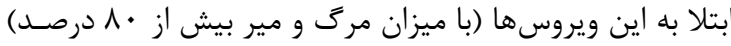

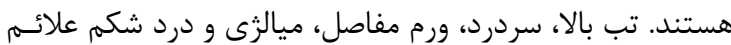

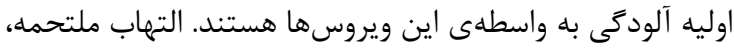

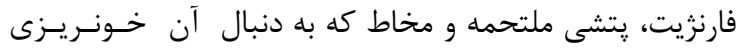

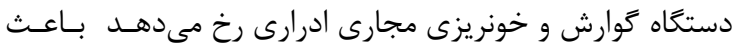

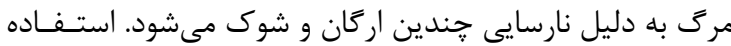

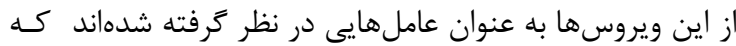

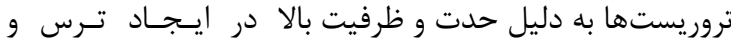

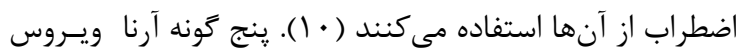

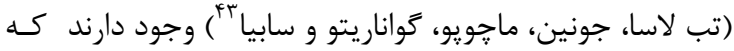

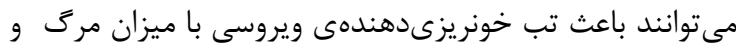

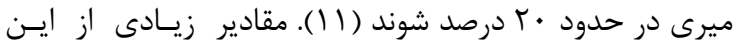

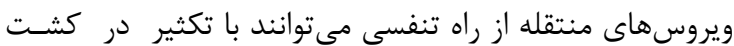

40- Hemorrhagic fever

41- Ebola

42- Marburg

43- Sabia 
كوويد 9 (و...)، كاما (كرونا ويروس :برند

جدول r. طبقه بندى مهم ترين جنسهاى خانواده كرونا ويروس(19)

\begin{tabular}{|c|c|c|}
\hline بيمارى & ويروس & تروه \\
\hline سرماخوردگى، ينومونى & 229E كرونا ويروس انسانى & \multirow{6}{*}{ كروه آلفا } \\
\hline برونشيوليت "، سرماخوردگى، ينومونى & كرونا ويروس انسانى NL63 & \\
\hline ينومونى، كاستروانتريت & ويروس كاستروانتريت •ه مسرى خوى & \\
\hline كاستروانتريت & كرونا ويروس سگ & \\
\hline يريتونيت، انتريت & ويروس يريتونيت اه عفونى گربه & \\
\hline بدون علائم (تنفسى، روده اى) & كرونا ويروس خفاش & \\
\hline سرماخوردگى، ينومونى & كرونا ويروس انسانى OC43 & \multirow{7}{*}{ كروه بتا } \\
\hline ينومونى & كرونا ويروس انسانى HKU1 & \\
\hline هياتيت، آنسفاليت هf & ويروس هياتيت & \\
\hline ينومونى، كاستروانتريت & كرونا ويروس كاو & \\
\hline ينومونى، كاستروانتريت، علائمى شبيه & SARS Sرونا ويروس & \\
\hline عفونت دستخاه تنفسى فوقانى و تحتانى & Sرونا ويروس MERS & \\
\hline عمدتا عفونت دستخاه تنفسى تحتانى & كرونا ويروس 2 -SOVID 19)SARS) & \\
\hline تراكئيت هـ، عفونت كليه & كرونا ويروس برونشيت يرندگان & كروه كاما \\
\hline Fاستروانتريت & كرونا ويروس خوكى HKU15 & كروه دلتا \\
\hline
\end{tabular}

\section{سندروم تنفسى حاد شديد (سارس)}

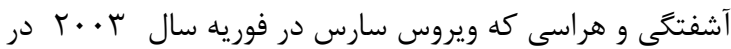

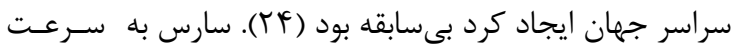

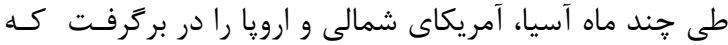

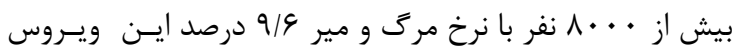

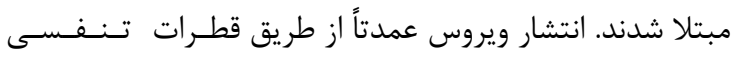

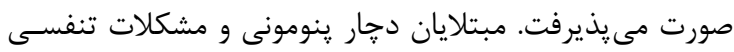

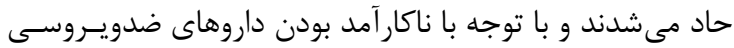

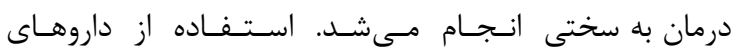

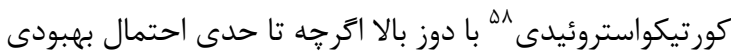

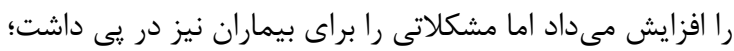

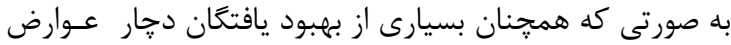

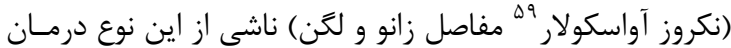

48- Pneumonia

49- Bronchiolitis

50- Gastroenteritis

51- Peritonitis

52- Enteritis

53- Hepatitis

54- Encephalitis

55- Tracheitis

56- Rhinovirus

57- Nasopharynx

58- Corticosteroids

59- Avascular necrosis
كرونا ويروس انسانى 229E

كرونا ويروس 229Eدر سال 1999 هنغامى كه محققان در حال

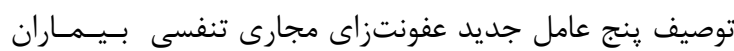

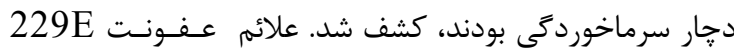

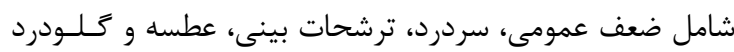

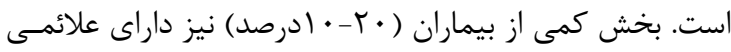

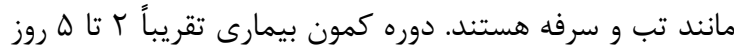

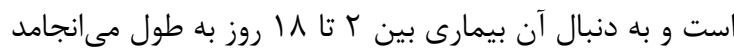

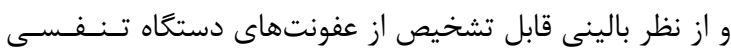

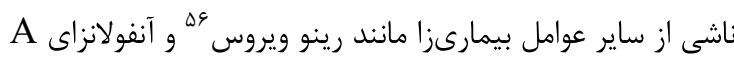

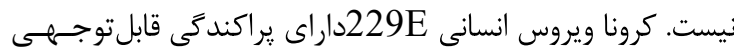

در سرتاسر دنيا نيز هست (· •Y-TY).

\section{كرونا ويروس انسانى OC43}

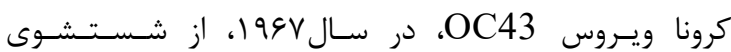

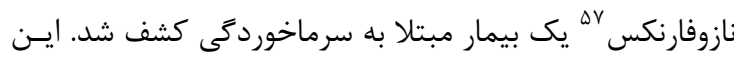

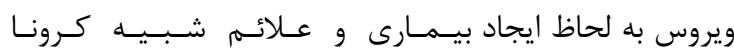

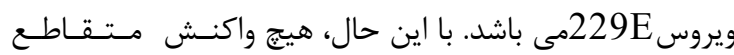

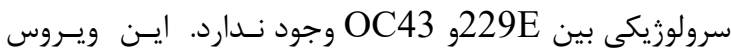
همانند ساير كرونا ويروس ها داراى توزيع قابل توجهى در سطح

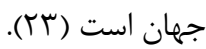


زيادى برخوردار است تا بتوان اين ويروس و ويروسهاى مشابـه

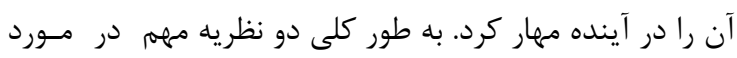

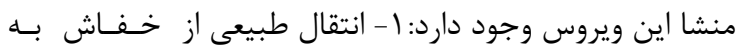

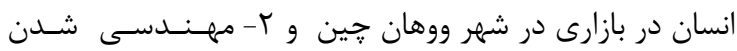

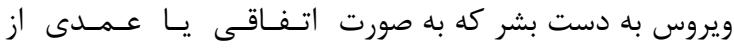

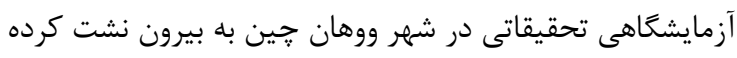

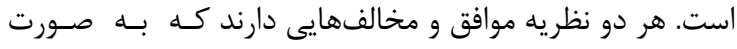

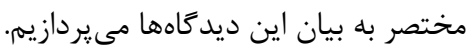

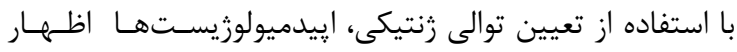

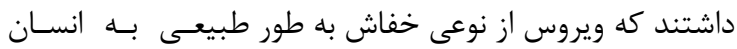

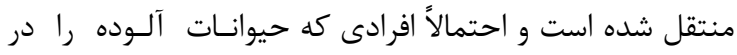

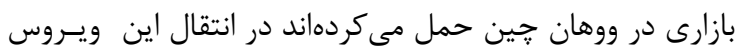

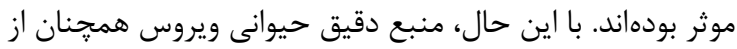

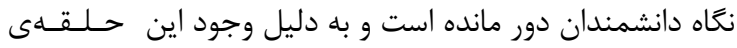

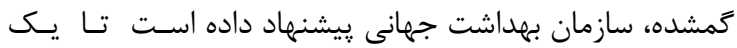

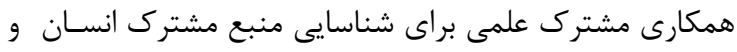

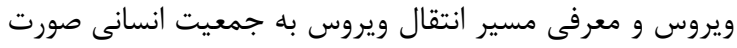
يذيرد تا بتوان راهكارى جهت مقابله با اين ويروس اتخاذ كرد. از

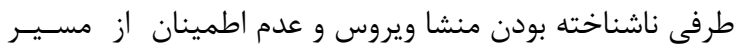

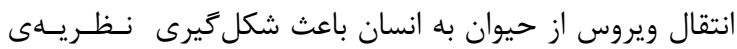

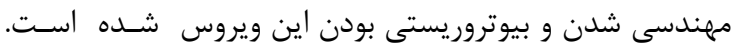

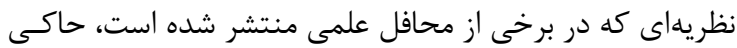

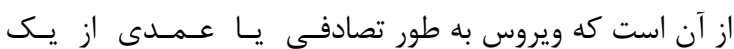

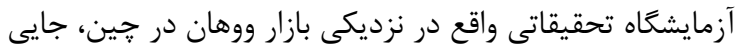

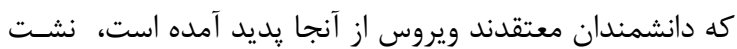

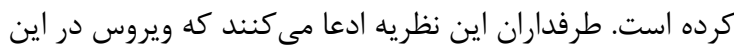

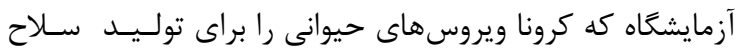

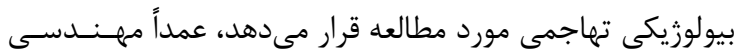

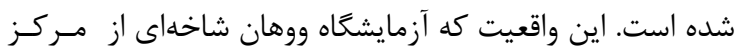

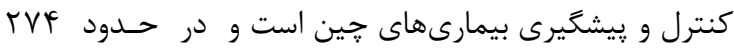

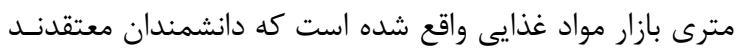

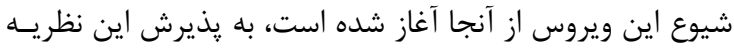

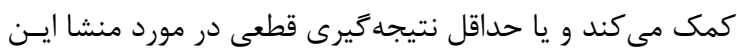

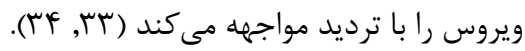

\section{r- نقش حيوانات به عنوان مخازن عوامل بيولوزيك}

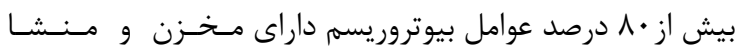

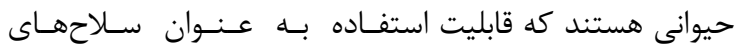

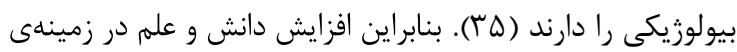

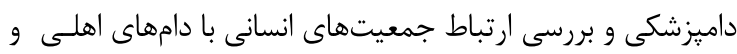

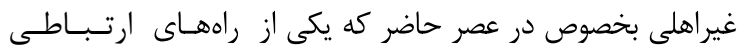

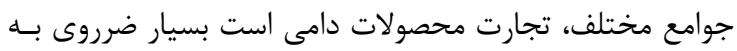

هستند (YQ) . توالى زنومى به دست آمده از كروناويـروسهـايسى

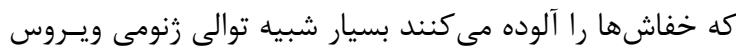

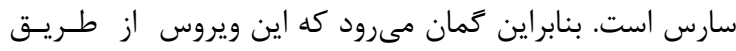
خفاش و سيس بواسطه يك ميزبان واسط به انسان منتقل شئ شده

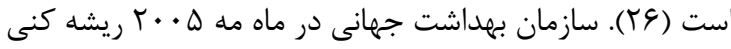

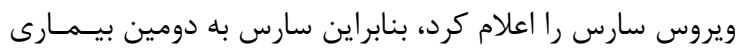

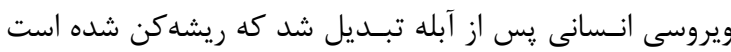

\section{سندرم تنفسى خاورميانه (مرس)}

سندروم تنفسى خاورميانه نيز يك كرونا ويروس جديد است كه

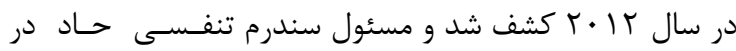

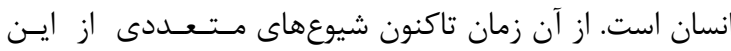
ويروس به خصوص در شبه جزيره عربستان ززارش شده است و

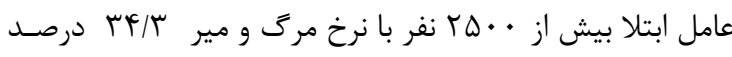

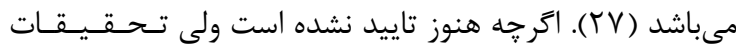

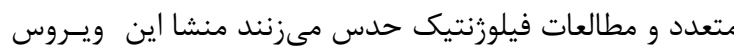

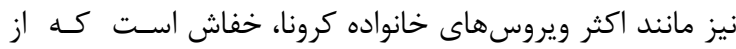
طريق شتر به انسان منتقل شده است. به دليل مرى و و مير مير بالا،

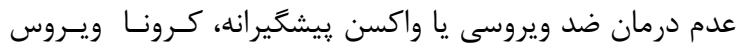
مرس يكى از نكرانى هاى عمده عمومى است (Y^).

\section{كرونا ويروس SARS- 2 (بيمارى كرونا ويروس 19)} شيوع يك ينومونى كشندهى مرموز در روزهاى يـايـانى سـ سـال

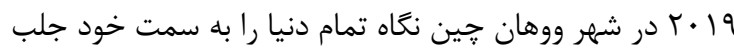

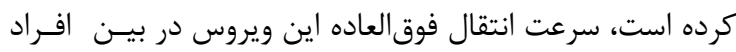

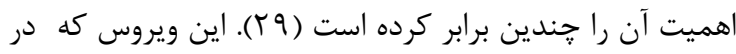

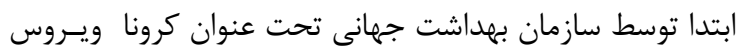
جديد (nCoV) لقب گرفته بود هم اكنون با نام بيمارى كـرونـا

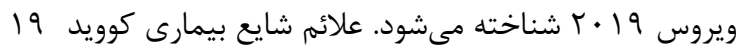

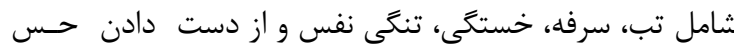

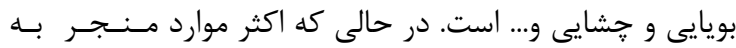

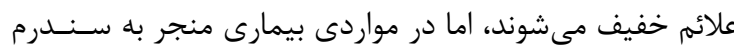

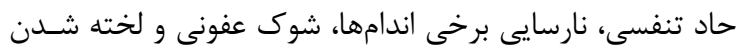

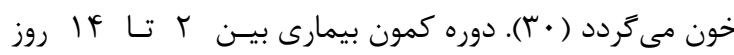

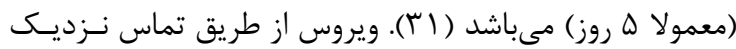

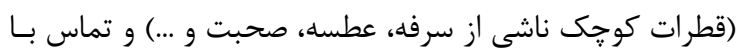

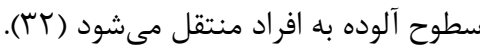

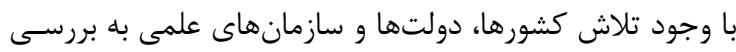

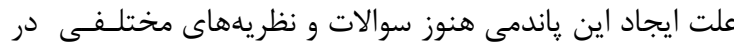

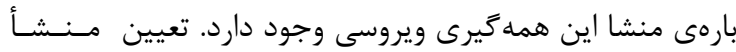

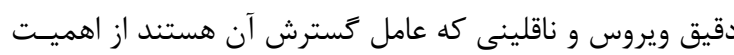


إيدميولوزيست دانشكاه كاليفرنيا، سلامت جهانى رامىتوان در

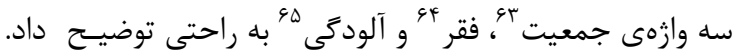

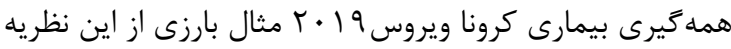

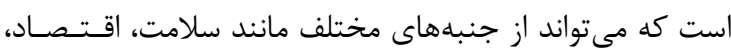

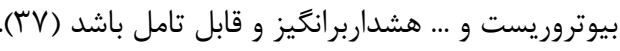

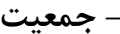

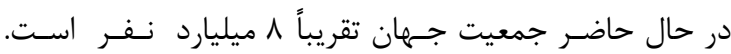

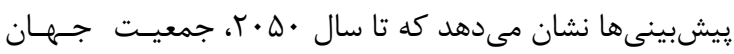

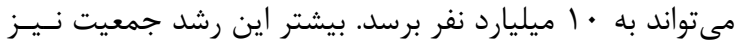

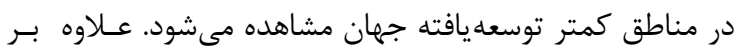

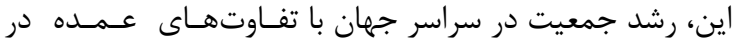

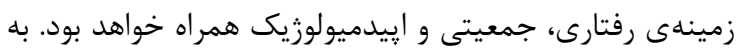

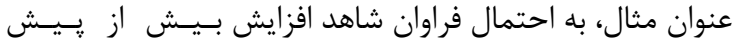

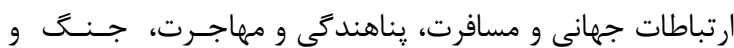
دركيرى، مبادله كالا و اطلاعات، مصرف غيرمسئولانهان، نإِايدارى

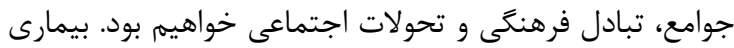

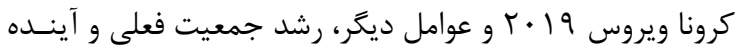

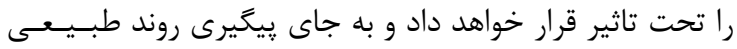

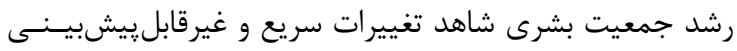

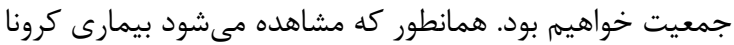

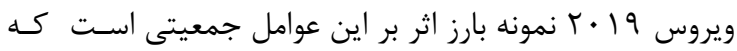

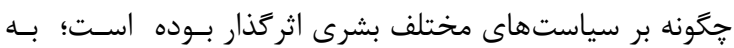

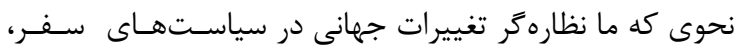

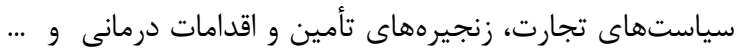

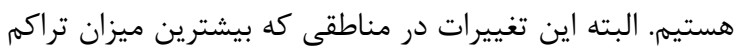

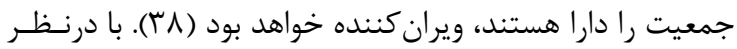

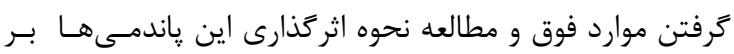

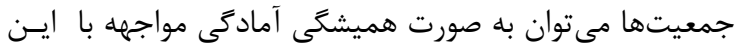

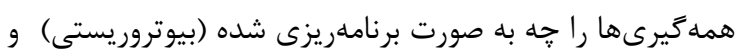

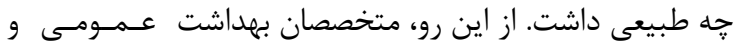

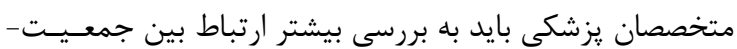

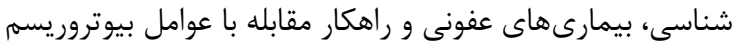
به خصوص در جمعيتهاى متراكم كه احتمال انتقال سريع تر و و بردي تلفات بيشترى وجود دارد بيردازند.

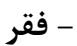
يكى از عوامل مههم و تاثير كذار در سلامت افراد، جوامع و مـلـل، دئ.

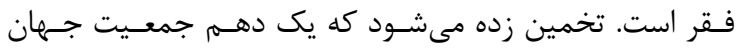

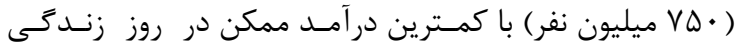

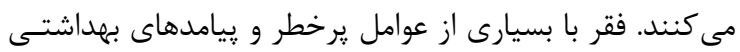

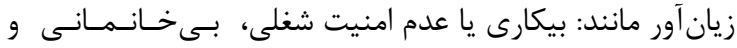

63- Population

64- Poverty

65- Pollution
نظر مىرسد. تمايل انسان به استفاده از گوشت و مـحـصـولات

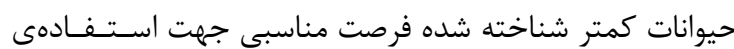

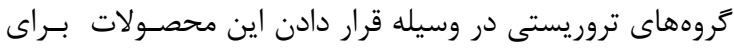

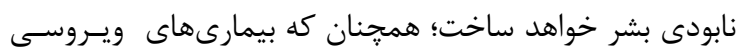

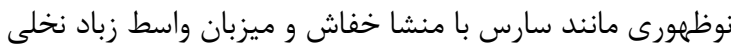
آسيايى •4 (نوعى كربه آسيايى)، مرس با منشا خفاش باش و ناقل شتر

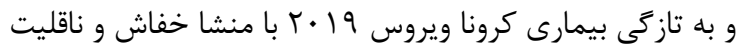

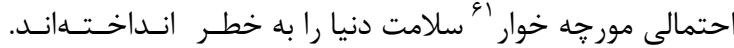

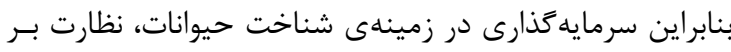

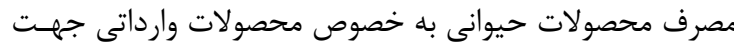

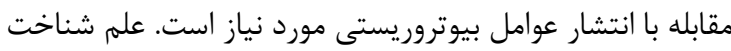

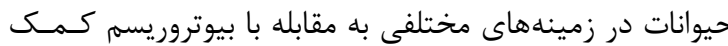
مى كند: - تشخيص زود هنحًام علائم بالينى در حيوانات قبل از ظـهـور

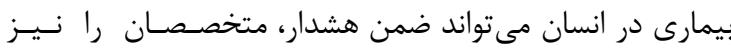

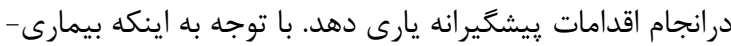

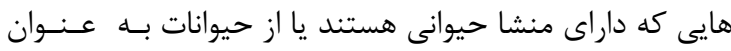

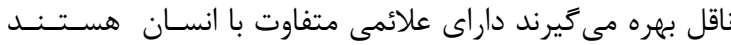

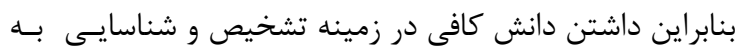
بشر جهت اقدامات سريعتر و مناسبتر كمك مى كند (ع دم). - ظهور همززمان علائم و نشانههاى بيمارى در حيوانات ممـكــن

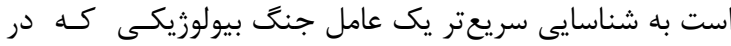

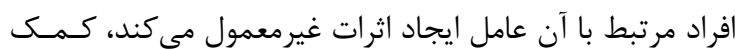

كند (צץ).

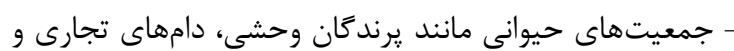
حيواناتى كه در تجارت داخلى يا بينالمللى حيوانات اسـتـفــاده

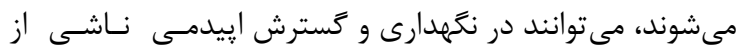

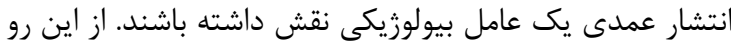

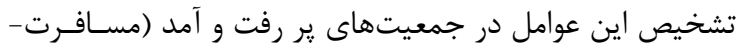

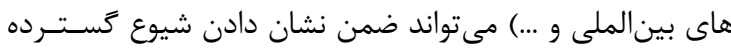

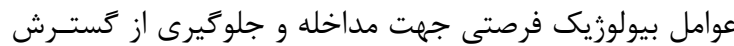
بيشتر اين عوامل فراهم آورد (ع) بورئ.

\section{ץ- جالشهاى بيش روى بشر بعد از بيمارى كرونا ويروس} $r+19$

با نغاهى به ديد كاههاى مختلف دانشمندان مىتوان به ر راحـتى

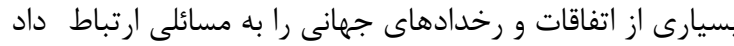

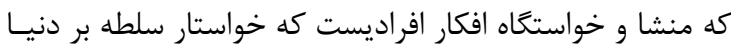

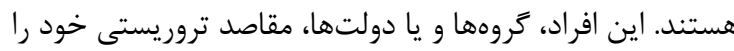

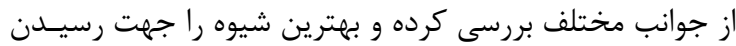

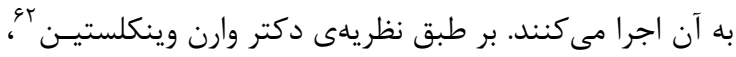

60- Asian palm civet

61- Pangolin

62- Warren Winkelstein Jr 
در شيوع آنفلوانزاى مرغى در سال r +. د در جين مشاهده كرد

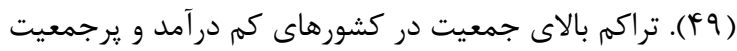

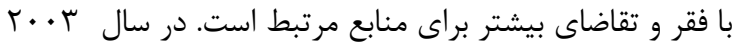

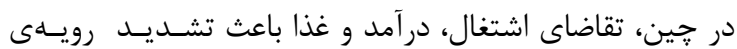
دامدارى بدون ايمنى و بهداشت شد. اين تقاضا باعث افزايش در

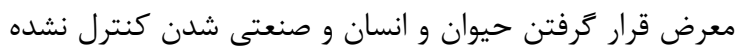

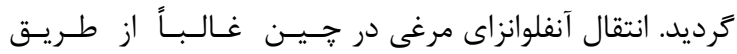

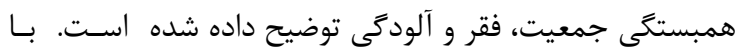

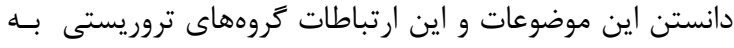

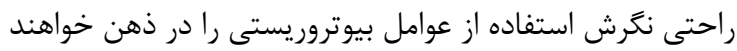

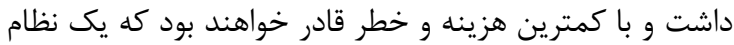

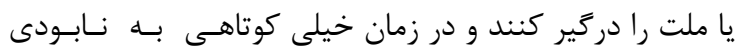
بكشانند.

\section{بحث و نتيجه گيرى}

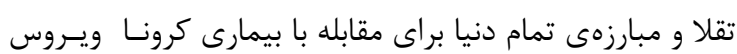

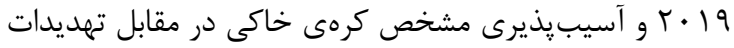

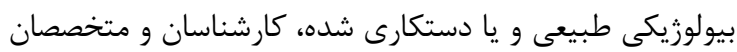

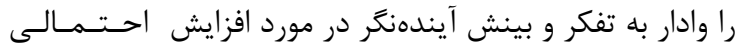

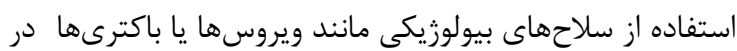

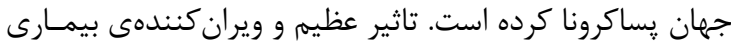

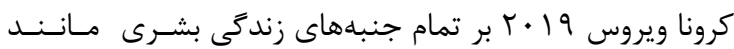
اقتصاد و سلامت، احتمال تمايل گروههاى تروريستى به استفاده

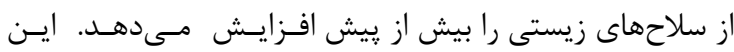

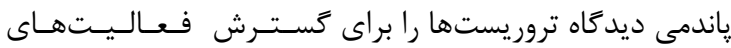

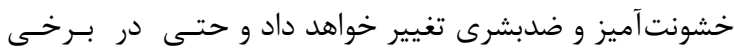

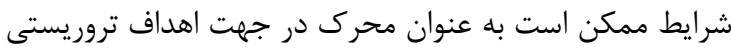
عمل كند. دولتها و متخصصان سلامت نه تنها براى بيمارى هـمـهــــــر

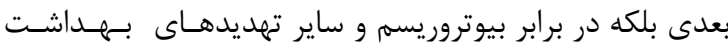

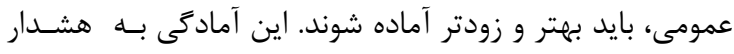

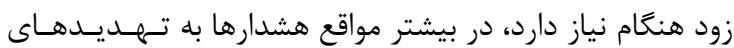

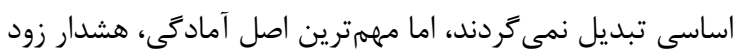

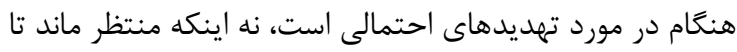

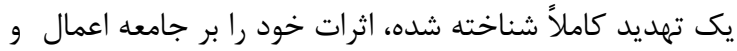

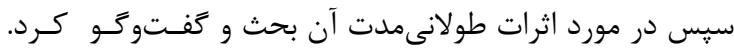

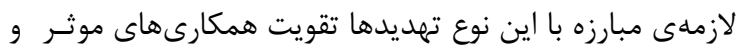

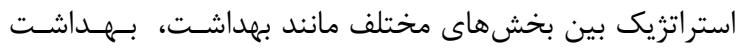

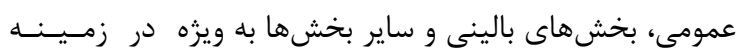

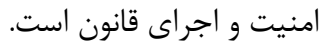

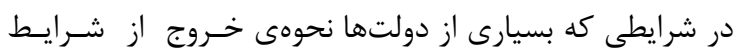

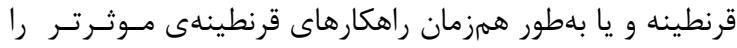

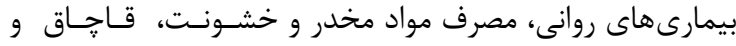

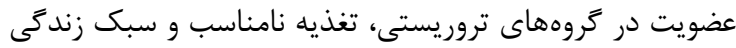
ناسالم، افزايش شهرنشينى و صنعتى شدن كنترل نشده، كاهش

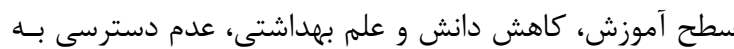

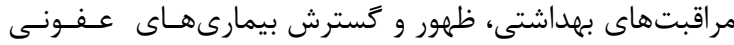

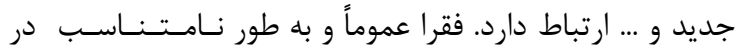

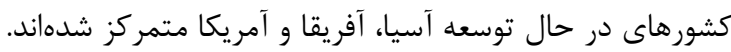

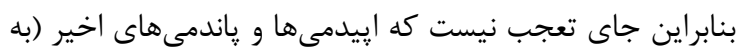

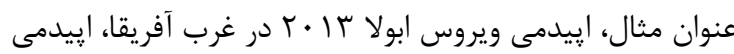

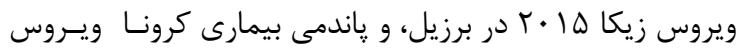

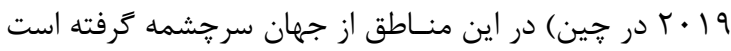

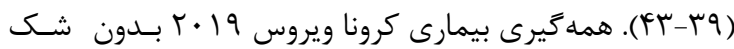

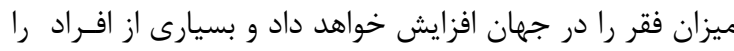

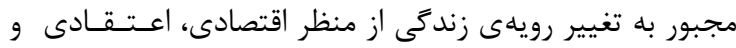

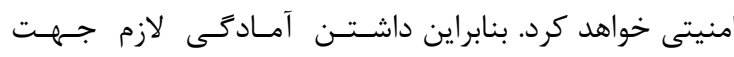

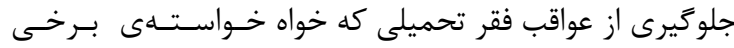

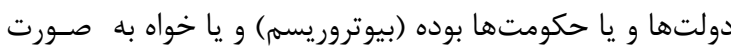
طبيعى اتفاق افتاده ضرورى به نظر مئرسد.

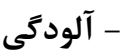

سومين عامل مههم در سلامتى بشر، آلودگى است. اخر جه قــــلاً

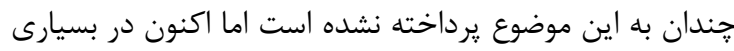

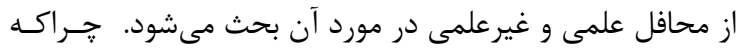

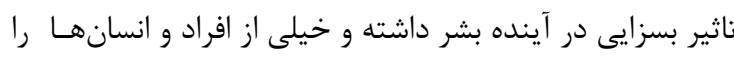

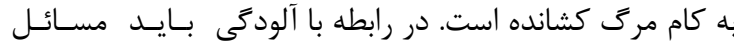

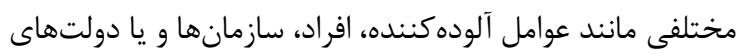

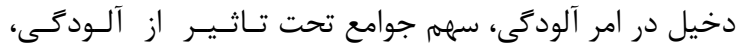

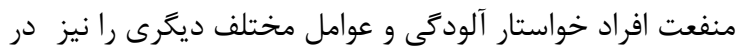

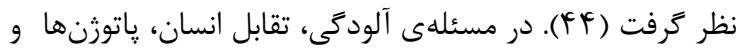

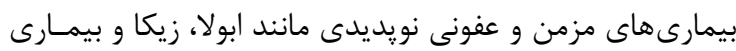

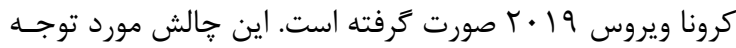

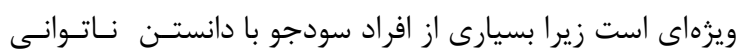

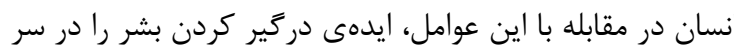

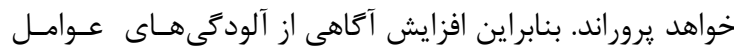

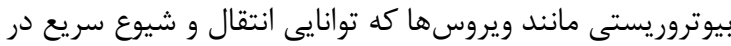

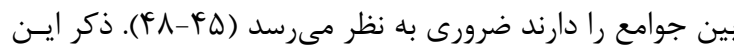

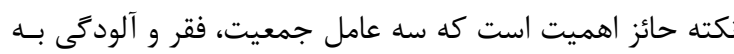

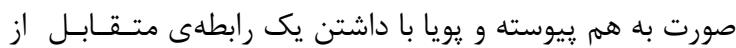

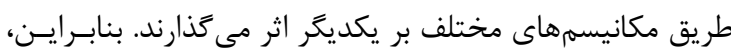

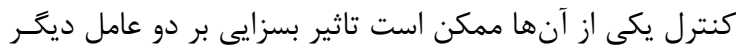

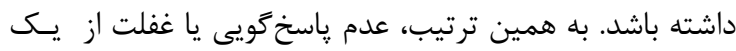

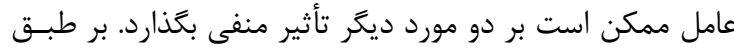

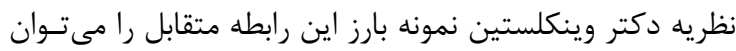


خواهند بود از كشندَى اين ويروسها الكَ كَرفته و با روشهاى

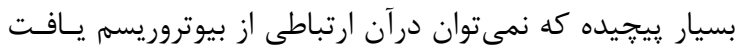

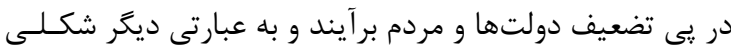

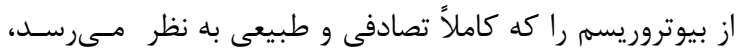

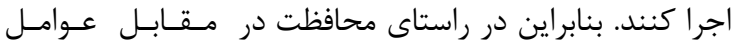

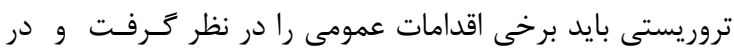

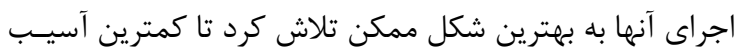
وارده را متحمل شد.

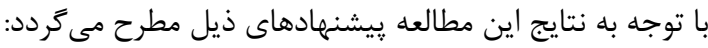

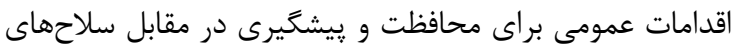

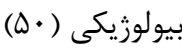

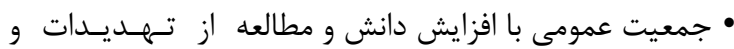

خطرات ناشى از عوامل بيولوزيكى آكاه كر دند.

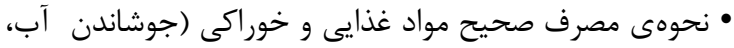

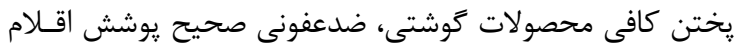
خوراكى در زنجيره انتقال و ...) به افراد آموزش دادئ داده شودات • • آغاز سريع اقدامات كنترل حشرات و جوندات واندان • جداسازى موارد مشكوك و داراى علائم بالينى از ساير افـراد جامعه • تشخيص اوليه و دقيق كليد مديريت تلفات جنگ بيولوزيكى إنى

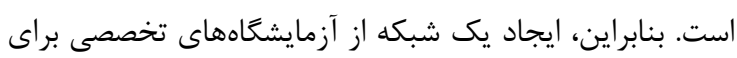
تشخيص آزمايشحاهى ضرورى به نظر مى برسد.

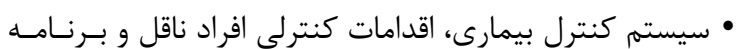

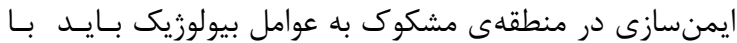
جديت بيشترى دنبال شود.

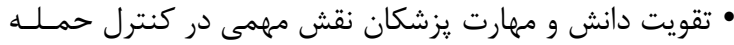

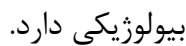

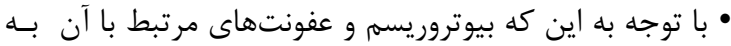

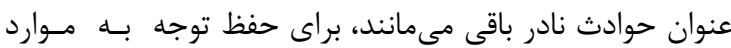

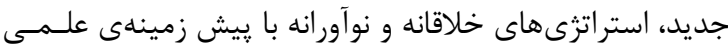
در مقابله با اين دست از حملات لازمات است است
بررسى مى كنند، تأثير بيمارى كرونا ويروس 9 1. ب بر بهداشت و

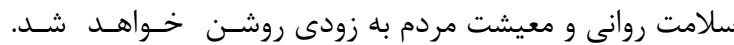

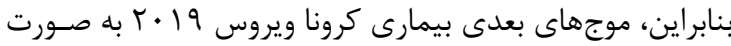

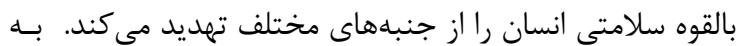
كفته اقتصاددانان، انتظار مىرود ركود اقتصادى در سراس استر جهان إنان

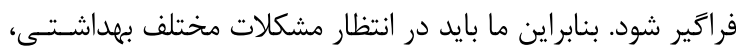

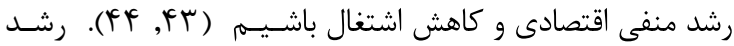
منفى اقتصادى باعث اثرات زيانبارى بر سلامتى و مركى و مسيـر

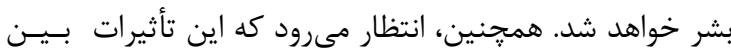

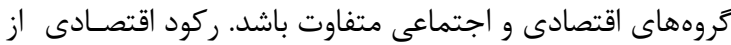

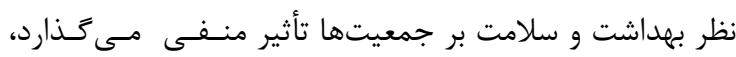

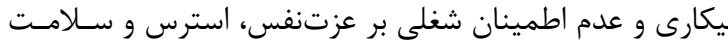

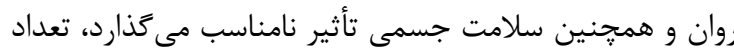

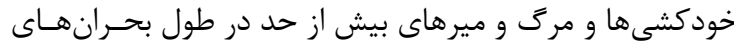

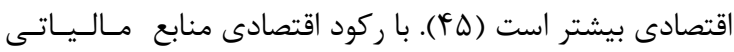
كمترى در دسترس خواهد بود كه اين امر دسترسى به مراقبت

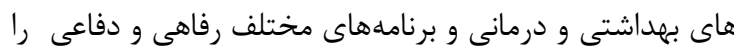

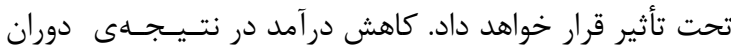
مقابله با عواملى مانند بيمارى كرونا ويروس

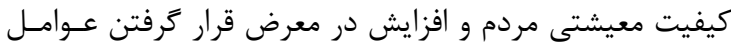

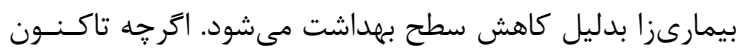

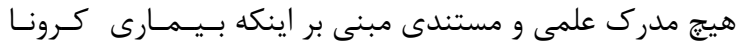

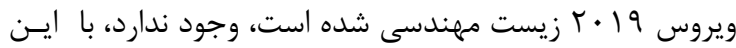

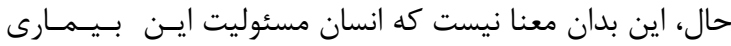

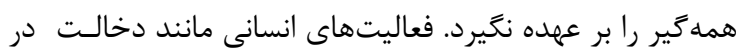

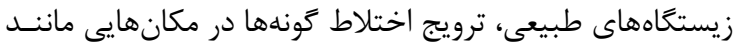

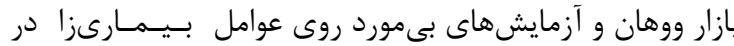

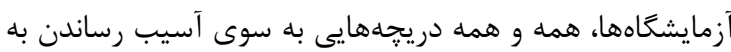
بشر و محيط است.

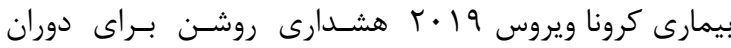

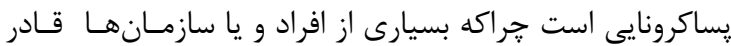




\section{References:}

1.-Pal M, Tsegaye M, Girzaw F, Bedada H, Godishala V, Kandi V. An overview on biological weapons and bioterrorism. Am J Biomed Res. 2017;5(2):24-34.

2-Bhattacharjee T, K.T.Shanmugam, Babu N, Masthan KMK. Virus as a biological-weapon. 2018.

3-Trevisanato SI. The 'Hittite plague', an epidemic of tularemia and the first record of biological warfare. Medical hypotheses. 2007;69(6):1371-4.

4-Mollaret H. Bref historique de la guerre bactériologique. Médecine et maladies infectieuses. 1985;15(7):402-6.

5-Dickinson LE. Military role in countering terrorist use of weapons of mass destruction. AIR WAR COLL MAXWELL AFB AL; 1999.

6-Calisher $\mathrm{CH}$. Bioterrorism or natural disasters: what shall we worry about next? Croatian medical journal. 2007;48(4):574.

7-Bioterrorism Agents/Diseases CDC $24 / 7$.saving lives, protecting people,reducing health costs [Internet]. 2020.

8-McFadden G. Killing a killer: what next for smallpox? PLoS Pathog. 2010;6(1):e1000727e.

9-Patwa J, Flora S. Medical management of diseases associated with biological warfare. Handbook on Biological Warfare Preparedness: Elsevier; 2020. p. 151-72.

10-Rotz LD, Khan AS, Lillibridge SR, Ostroff SM, Hughes JM. Public health assessment of potential biological terrorism agents. Emerg Infect Dis. 2002;8(2):225-30.

11-Zaza AD, Herbreteau CH, Peyrefitte CN, Emonet SF. Past, present and future therapeutic and prophylactic strategies against arenaviruses responsible of human hemorrhagic fever. Virologie. 2017;21(6):267-85.

12-Sidwell R, Smee D. Viruses of the Bunyaand Togaviridae families: Potential as bioterrorism agents and means of control. Antiviral research. 2003;57:101-11.

13-Taylor LH, Latham SM, Woolhouse ME. Risk factors for human disease emergence. Philos Trans R Soc Lond B Biol Sci. 2001;356 (1411):983-9.

14-Woolhouse MEJ, Gowtage-Sequeria S. Host range and emerging and reemerging pathogens. Emerg Infect Dis. 2005;11(12):1842-7.

15-Morens DM, Fauci AS. Emerging infectious diseases: threats to human health and global stability. PLoS Pathog. 2013;9 (7):e1003467-e.

16-Centres for disease control and prevention, Emerging infectious disease [Internet]. 2020.
17-Durham PJ, Stevenson BJ, Farquharson BC. Rotavirus and coronavirus associated diarrhoea in domestic animals. New Zealand veterinary journal. 1979;27(3):30-2.

18-MERS and SARS situation update [Internet]. 2020.

19-Coronaviridae, Taxonomy [Internet]. 2020.

20-Hamre D, Procknow JJ. A new virus isolated from the human respiratory tract. Proceedings of the Society for Experimental Biology and Medicine Society for Experimental Biology and Medicine (New York, NY). 1966;121(1):190-3.

21-Tyrrell D, Cohen S, Schilarb J. Signs and symptoms in common colds. Epidemiology \& Infection. 1993;111(1):143-56.

22-Monto AS. Medical reviews. Coronaviruses. The Yale journal of biology and medicine. 1974;47(4):234.

23-McIntosh K, Dees JH, Becker WB, Kapikian AZ, Chanock RM. Recovery in tracheal organ cultures of novel viruses from patients with respiratory disease. Proc Natl Acad Sci U S A. 1967;57(4):933-40.

24-Tsang KW, Ho PL, Ooi GC, Yee WK, Wang $T$, Chan-Yeung $M$, et al. A cluster of cases of severe acute respiratory syndrome in Hong Kong. New England Journal of Medicine. 2003;348(20):1977-85.

25-Tsang KW. Severe acute respiratory syndrome (SARS). International Encyclopedia of Public Health. 2017:477.

26-Robin M. Scientists trace 2002 Sars virus to colony of cave-dwelling bats in China. The Guardian. 2017.

27-MERS outbreaks [Internet].

28-Mohd HA, Al-Tawfiq JA, Memish ZA. Middle East respiratory syndrome coronavirus (MERS-CoV) origin and animal reservoir. Virology journal. 2016;13(1):87.

29-COVID 19 situation update [Internet]. may 2020.

30-Symptoms of Coronavirus [Internet]. 2020.

31-Velavan T, Meyer C. The Covid-19 epidemic. Tropical Medicine \& International Health. 2020;25.

32-Bourouiba L. Turbulent Gas Clouds and Respiratory Pathogen Emissions: Potential Implications for Reducing Transmission of COVID-19. JAMA. 2020;323(18):1837-8.

33-Ackerman G, Peterson H. Terrorism and COVID-19. Perspectives on Terrorism. 2020;14(3):59-73.

34-Bolsen T, Palm R, Kingsland JT. <? covid19?> Framing the Origins of COVID-19. Science Communication. 2020;42(5):562-85.

35-Cutler SJ, Fooks AR, van der Poel WHM. Public health threat of new, reemerging, and neglected zoonoses in the industrialized world. Emerg Infect Dis. 2010;16(1):1-7. 
36-Cottrell T, Morgan E. Animal surveillance in NBC defensive operations. BMJ Military Health. 2003;149(3):225-30.

37-Winkelstein W, Jr. Determinants of worldwide health. Am J Public Health. 1992;82(7):931-2.

38-Khubchandani J, Jordan TR, Yang YT. Ebola, Zika, Corona... What Is Next for Our World? Int J Environ Res Public Health. 2020;17(9):3171.

39-Waage J, Yap C, Bell S, Levy C, Mace G, Pegram T, et al. Governing the UN sustainable development goals: interactions, infrastructures, and institutions. The Lancet Global health. 2015;3(5):e251-2.

40-Merson MH, Black RE, Mills AJ. Global health: Diseases, programs, systems, and policies: Jones \& Bartlett Publishers; 2011.

41-McMichael AJ. Globalization, climate change, and human health. New England Journal of Medicine. 2013;368(14):1335-43.

42-Phelan AL, Katz R, Gostin LO. The novel coronavirus originating in Wuhan, China: challenges for global health governance. Jama. 2020;323(8):709-10.

43-Barua S. Understanding Coronanomics: The economic implications of the coronavirus (COVID-19) pandemic. SSRN Electronic Journal https://doi org/10/ggq92n. 2020.

44-Zafari M, Aghajani S, Mansouri Boroujeni M, Nosrati H. Vancomycin-loaded electrospun polycaprolactone/nano-hydroxyapatite membrane for the treatment of blood infections. Medical Hypotheses. 2020;144:109992.
45-Landrigan PJ, Fuller R, Acosta NJR, Adeyi O, Arnold R, Basu NN, et al. The Lancet Commission on pollution and health. Lancet (London, England). 2018;391(10119):462-512. 46-Heymann DL, Chen L, Takemi K, Fidler DP, Tappero JW, Thomas MJ, et al. Global health security: the wider lessons from the west African Ebola virus disease epidemic. The Lancet. 2015;385(9980):1884-901.

47-Zafari M, Mansouri Boroujeni M, Omidghaemi S, Yazdani A, Pourmotabed S, Hasanpour Dehkordi A, et al. Physical and biological properties of blend-electrospun polycaprolactone/chitosan-based wound dressings loaded with N-decyl-N, N-dimethyl-1decanaminium chloride: $\mathrm{An}$ in vitro and in vivo study. Journal of Biomedical Materials Research Part B: Applied Biomaterials. 2020;108(8):3084-98.

48-Nosrati H, Khodaei M, BanitalebiDehkordi M, Alizadeh M, Asadpour S, Sharifi $\mathrm{E}$, et al. Preparation and characterization of poly(ethylene oxide)/zinc oxide nanofibrous scaffold for chronic wound healing applications. Polimery w medycynie. 2020;50(1):4151.

49-Khubchandani J, Jordan TR, Yang YT. Ebola, Zika, Corona... What Is Next for Our World? : Multidisciplinary Digital Publishing Institute; 2020.

50-Bioterrorism agents /diseases [Internet]. 2020 . 